\title{
Sistem Pendukung Keputusan Pemilihan Menu Bagi Penderita Hipertensi
}

\author{
Harris Adhi Oktaviantho Suparno, Oktavian A. Lantang, Arie S. M. Lumenta \\ Teknik Infromatika Universitas Sam Ratulangi \\ 110216084@student.unsrat.ac.id, oktavian_lantang@unsrat.ac.id, al@unsrat.ac.id
}

\begin{abstract}
Abstrak - Hipertensi masih merupakan tantangan besar di Indonesia. Ketidakpahaman penderita mengenai penyakit hipertensi merupakan suatu kendala dalam penyembuhan. Sistem Pendukung Keputusan (SPK) dapat membantu manusia dalam mengambil keputusan, sehingga tidak merasa ragu-ragu dan informasinya akan lebih akurat. Pemecahan masalah adalah serupa dengan pengambilan keputusan ditambah dengan implementasi dari rekomendasi.

Dalam proses pengolahan data hingga memudahkan proses pengambilan keputusan, menggunakan metode Simple Additive Weighting $(S A W)$. Dengan metode Simple Additive Weighting (SAW) digunakan untuk menentukan makanan yang tepat berdasarkan kriteria-kriteria serta bobot yang sudah ditentukan. Data yang digunakan merupakan data yang diperoleh dari ahli gizi mengenai kandungan gizi yang berpengaruh dan makanan apa saja yang baik dikonsumsi oleh penderita hipertensi sesuai Angka Kecukupan Gizi.

Sistem Pendukung Keputusan Pemilihan Menu Bagi Penderita Hipertensi dengan menggunakan metode $S A W$ membantu bagi penderita hipertensi dalam menentukan menu makanan yang baik dengan memberikan rekomendasi makanan yang baik bagi penderita berupa ranking makanan berdasarkan bobot yang diperoleh.
\end{abstract}

Kata kunci : Hipertensi, Sistem Pendukung Keputusan (SPK), Simple Additive Weighting (SAW)

\section{PENDAHULUAN}

Hipertensi masih merupakan tantangan besar di Indonesia. hipertensi merupakan kondisi yang sering ditemukan pada pelayanan kesehatan primer kesehatan. Hal itu merupakan masalah kesehatan dengan prevalensi yang tinggi, yaitu sebesar 25,8\%, sesuai dengan data Riskesdas 2013. Hipertensi atau peningkatan tekanan darah adalah keadaan dimana supply oksigen dan nutrisi yang dibawa oleh darah terhambat dalam proses pengirimannya ke jaringan tubuh yang membutuhkan. Penyakit ini dapat menimbulkan gangguan pada organ tubuh yang lain karena menyebabkan organ-organ tersebut harus bekerja lebih keras. Tekanan darah pada umumnya meningkat seiring dengan meningkatnya usia dan berkaitan erat dengan terjadinya penyakit jantung serta stroke.Jadi yang peneliti lakukan adalah merancang aplikasi helpdesk untuk UPT-TIK dalam memberikan solusi untuk setiap pengeluhan-pengeluhan yang terjadi.

Ketidakpahaman penderita mengenai penyakit hipertensi merupakan suatu kendala dalam penyembuhan. Hal yang dibutuhkan adalah mengatur pola makan dan menghindari makanan yang dilarang (tinggi natrium dan lemak). Penderita hipertensi harus memperhatikan pola makanan, bisa mengotrol makanan yang dikonsumsi sehari-hari dianjurkan untuk melakukan diet sesuai kebutuhan, makanan yang rendah garam dan lemak, namun tinggi protein. Salah satu cara mencegah dan memelihara kesehatan agar terhindar dari penyakit hipertensi yaitu dengan pengaturan makanan. Tujuannya untuk menurunkan atau mempertahankan tekanan darah sehingga mencapai batas normal dan menghilangkan penimbunan garam.

Dengan kemajuan teknologi saat ini yang begitu pesat dan cepat berkembang bisa membantu manusia dalam berbagai bidang, tak terkecuali bidang kesehatan.. Sistem Pendukung keputusan dapat membantu manusia dalam mengambil keputusan, sehingga tidak merasa ragu-ragu dan informasinya akan lebih akurat. Pemecahan masalah adalah serupa dengan pengambilan keputusan ditambah dengan implementasi dari rekomendasi. Pemecahan masalah tak hanya mengacu ke solusi dari area masalah/kesulitan-kesulitan tapi mencakup juga penyelidikan mengenai kesempatan kesempatan yang ada.

Sistem pendukung keputusan pemilihan menu bagi penderita hipertensi menggunakan FMADM (Multiple Attribute Decission Making) dengan Metode SAW (Simple Additive Weighting) digunakan untuk menentukan makanan yang tepat berdasarkan kriteria-kriteria serta bobot yang sudah ditentukan. Metode ini dipilih karena mampu menyeleksi alternatif terbaik dari sejumlah alternatif. Sehingga dari sistem pengambilan keputusan pemilihan menu diharapkan dapat membantu bagi mereka penderita hipertensi.

\section{LANDASAN TEORI}

\section{A. SISTEM PENDUKUNG KEPUTUSAN}

Sistem Pendukung Keputusan merupakan suatu sistem interaktif yang mendukung keputusan dalam proses pengambilan keputusan melalui alternatif-alternatif yang diperoleh dari hasil pengolahan data, informasi dan rancangan model (Astri \& Utami, 2013).

Kusrini (dalam Amelia \& Rosiana. 2012) Sistem Pendukung Keputusan merupakan sistem informasi yang menyediakan informasi, pemodelan dan pemanipulasian data. Definisi lain Sistem pendukung keputusan adalah sistem tambahan, mampu untuk mendukung analis is data secara ad hoc dan pemodelan keputusan serta berorientasi pada perencanaan masa depan[1]. 


\section{B. Metode Simple Additive Weighting (SAW)}

Metode ini merupakan metode yang paling dikenal dan paling banyak digunakan orang dalam menghadapi situasi MADM (multiple attribute decision making).Metode ini mengharuskan pembuat keputusan menentukan bobot bagi setiap atribut. Skor total untuk sebuah alternatif diperoleh dengan menjumlahkan seluruh hasil perkalian antara rating (yang dapat dibandingkan lintas atribut) dan bobot tiap atribut.Rating tiap atribut haruslah bebas dimensi yang artinya telah melewati proses normalisasi sebelumnya (Murdani, 2013).

Asep (2012) metode SAW sering juga dikenal istilah metode penjumlahan terbobot. Konsep dasar metode SAW adalah mencari penjumlahan terbobot dari rating kinerja pada setiap alternatif pada semua atribut. Metode SAW membutuhkan proses normalisasi matriks keputusan (X) ke suatu skala yang dapat diperbandingkan dengan semua rating alternatif yang ada[4].

$$
\boldsymbol{r}_{i j}=\left\{\begin{array}{lr}
\frac{x_{i j}}{\operatorname{Max}_{i} x_{i j}} & \text { Jika } j \text { adalah atribut keuntungan (benefit) } \\
\frac{\operatorname{Min}_{i} x_{i j}}{x_{i j}} & \text { Jika } j \text { adalah atribut biaya (cost) }
\end{array}\right.
$$

dimana rij adalah rating kinerja ternormalisasi dari alternatif Ai pada atribut $\mathrm{Cj} ; \mathrm{i}=1,2, \ldots, \mathrm{m}$ dan $\mathrm{j}=1,2, \ldots, \mathrm{n}$. Nilai preferensi untuk setiap alternatif (Vi)diberikan sebagai :

$$
V_{i}=\sum_{j=1}^{n} w_{j} r_{i j}
$$

Keterangan :

$\mathrm{Vi}=$ rangking untuk setiap alternatif

wj = nilai bobot dari setiap kriteria

rij = nilai rating kinerja ternormalisasi

Nilai Vi yang lebih besar mengindikasikan bahwa alternatif Ai lebih terpilih.

\section{Unified Modeling Language (UML)}

Menurut Nugroho (dalam Lukman et al, 2014), Unified Modeling Language (UML) adalah bahasa pemodelan untuk sistem atau perangkat lunak yang berparadigma berorientasi objek. Pemodelan sesungguhnya digunakan untuk penyederhanaan permasalahan-permasalahan yang kompleks sedemikian rupa sehingga lebih mudah dipelajari dan dipahami[7].

$U M L$ sendiri juga memberikan standar penulisan sebuah sistem blue print, yang meliputi konsep bisnis proses, penulis an kelas-kelas dalam bahasa program yang spesifik, skema database, dan komponen- komponen yang diperlukan dalam sistem software. Notasi standar yang disediakan $U M L$ bisa digunakan sebagai alat komunikasi bagi para pelaku dalam proses analisis yaitu, diagram use case, diagram sequence, dan diagram class. Dengan menggunakan $U M L$ dapat membuat model untuk semua jenis aplikasi piranti perangkat lunak, dimana aplikasi tersebut dapat berjalan pada piranti perangkat keras, sistem operasi dan jaringan apapun, serta ditulis dalam bahasa pemrograman apapun. Tetapi karena $U M L$ juga menggunakan class dan operation dalam konsep dasarnya, maka UML cocok untuk penulisan piranti lunak dalam bahasa pemrograman yang berorientasi objek OOP (Object Oriented Programming) (Wiwekananda, tanpa tahun).

\section{Hipertensi}

Purnomo dalam Arista Novian (2013) derajat hipertensi atau yang lebih dikenal dengan sebutan penyakit darah tinggi adalah suatu keadaan dimana tekanan darah seseorang berada diatas batas normal atau optimal yaitu $120 \mathrm{mmHg}$ untuk sis tolik dan $80 \mathrm{mmHg}$ untuk diastolik. Penyakit ini dikategorikan sebagai the silent disease karena penderita tidak mengetahui dirinya mengidap hipertensi sebelum memeriksakan tekanan darahnya. Hipertensi yang terjadi dalam jangka waktu lama dan terus menerus bisa memicu stroke, serangan jantung, gagal jantung dan merupakan penyebab utama gagal ginjal kronik[3].

Menurut Baradiro dalam Arista Novian (2013) peningkatan tekanan darah juga dipengaruhi oleh beberapa faktor risiko antara lain meliputi umur, jenis kelamin, riwayat keluarga, obesitas, kadar garam tinggi, dan kebiasaan hidup seperti merokok dan minuman beralkohol. Bagi yang memiliki faktor resiko ini seharusnya lebih waspada dan lebih dini dalam melakukan upaya-upaya preventif, contohnya yang paling sederhana adalah rutin kontrol tekanan darah lebih dari satu kali, serta berusaha menghindari faktor-faktor pencetus hipertensi.

Natrium dan kalium adalah kation utama dalam cairan ekstraseluler tubuh yang mempunyai fungsi mengatur keseimbangan cairan dan as ambasa tubuh serta berperan dalam trans misi saraf dan kontraksi otot. Asupan yang berlebih dapat menyebabkan gangguan keseimbangan tubuh, sehingga dapat menyebabkan oedema, asites dan hipertensi (Listiyaningsih et al., 2014).

\section{E. Model Waterfall}

Model waterfall menggambarkan pembangunan perangkat lunak seperti aliran air terjun, mulai analysis requirement sebagai awal proses sampai dengan deployment dan maintenance di akhir proses. Model waterdall berisi rangkaian aktivitas proses. Setiap tahapan disajikan dalam proses yang terpisah secara ketat, seperti spesifikasi kebutuhan, desain, implementasi perangkat lunak, uji coba, dan seterusnya. Walaupun langkah mundur ke tahapan sebelumnya masih dimungkinkan, namun pada dasarnya tahapan ini tidak 
menghendaki adanya langkah mundur (Arianto et al. tanpa tahun).

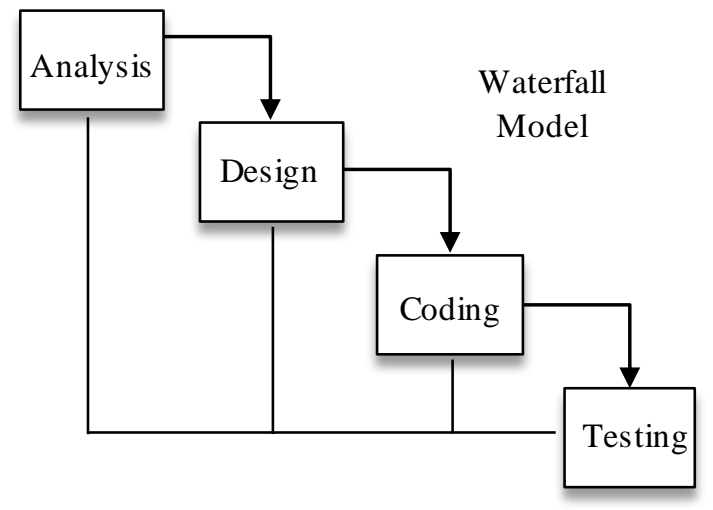

Gambar 1 Waterfall Model

Fase dalam model Waterfall adalah:

\section{- Analisis}

Langkah ini merupakan analisa terhadap kebutuhan sistem. Pengumpulan data dalam skripsi ini menggunakan wawancara/observasi langsung serta study literatur, Semua kebutuhan yang mungkin diperlukan dikumpulkan guna membangun suatu sistem yang baik

\section{- Desain}

Desain perangkat lunak berkaitan dengan struktur data, arsitektur perangkat lunak, representasi interface, dan detail (algoritma). Desain Sistem: Spesifikasi kebutuhan dari tahap pertama dipelajari dalam fase ini dan desain sistem disiapkan. Desain Sistem membantu dalam menentukan perangkat keras dan sistem persyaratan dan juga membantu dalam mendefinisikan arsitektur sistem secara keseluruhan.

\section{- Coding}

Tahap penerjemahan desain sistem dalam bentuk bahasabahasa pemrograman tertentu. Pelaksanaan: Dengan masukan dari desain sistem, sistem ini pertama kali dikembangkan dalam program kecil yang disebut unit, yang terintegrasi dalam tahap berikutnya.

\section{- Testing}

Setelah coding, tahap perangkat lunak di uji dengan metode black box untuk memastikan bahwa perangkat lunak yang dibuat sesuai dengan desain dan dapat digunakan oleh user . Seluruh sistem diuji untuk setiap kesalahan dan kegagalan untuk diperbaiki agar layak digunakan.

\section{F. $P H P$}

PHP adalah singkatan dari Perl Hypertext PreProcessors, PHP saat ini adalah bahasa pemrograman interpreter yang paling banyak digunakan saat ini dikarenakan bersifat open source dan juga paling banyak didukung oleh banyak web server. PHP dapat digunakan oleh banyak sis tem operasi s eperti Windows, dan Linux.

PHP adalah bahas a scripting yang menyatu dengan HTML dan dijalankan pada serverside. Artinya semua sintaks yang diberikan akan sepenuhnya dijalankan pada server, sedangkan yang dikirimkan ke browser hanya hasilnya saja. Ketika seorang pengguna internet membuka suatu situs yang menggunakan fasilitas server side scripting PHP, maka terlebih dahulu server bersangkutan akan memproses semua perintah PHP di server lalu mengirimkan hasilnya dalam format HTML ke web server pengguna (Arianto et al. tanpa tahun).

PHP memiliki beberapa kelebihan yang tidak dimiliki oleh bahasa-bahasa sejenisnya, yaitu:

- Bahasa pemrograman PHP adalah sebuah bahasa script yang tidak melakukan sebuah kompilasi dalam penggunaanya.

- Web Server yang mendukung PHP dapat ditemukan dimana - mana dari mulai IIS sampai dengan apache, dengan configurasi yang relatif mudah.

- Dalam sisi pengembangan lebih mudah, karena banyaknya milis - milis dan developer yang siap membantu dalam pengembangan.

- Dalam sisi pemahamanan, PHP adalah bahasa scripting yang paling mudah karena referensi yang banyak.

- PHP adalah bahasa open source yang dapat digunakan di berbagai mesin (linux, unix, windows) dan dapat dijalankan secara runtime melalui console serta juga dapat menjalankan perintah-perintah sistem (Utami, 2012).

\section{G. $M y S Q L$}

MySQL adalah salah satu jenis database server yang sangat terkenal. Kepopulerannya disebabkan oleh MySQL menggunakan SQL sebagai bahasa dasar untuk mengakses databasenya. Selain itu, ia bersifat free pada berbagai platform (kecuali pada Windows, yang bersifat shareware atau Anda perlu membayar setelah melakukan evaluasi dan memutuskan digunakan untuk keperluan produksi) (Arianto et al. tanpa tahun).

Menurut Nugroho (dalam Wiwekananda, tanpa tahun)MySQL adalah sebuah program basis data server yang mampu menerima dan mengirim datanya dengan sangat cepat, multi user serta menggunakan perintah standar SQL(structured query language). MySQL dapat juga berperan sebagai client sehingga sering disebut database client/server, yang open source dengan kemampuan dapat berjalan baik di OS (operating system).

\section{Metodologi Penelitian}

\section{A. Kerangka Berpikir}

Kerangka berpikir dalam metodologi penelitian ini dibuat seperti pada gambar 2 dimulai dengan perumusan masalah lewat masalah-masalah yang ada dalam membangun sistem pendukung keputusan kemudian mengumpulkan data-data penelitian yang diperlukan. Kemudian merancang bangun sistem pendukung keputusan lalu diadakan pengujian jika masih error maka diperiksa kembali sistem pendukung keputusan jika ada yang bermasalah, tetapi jika berhasil maka selesai membuat sistem pendukung keputusan. 


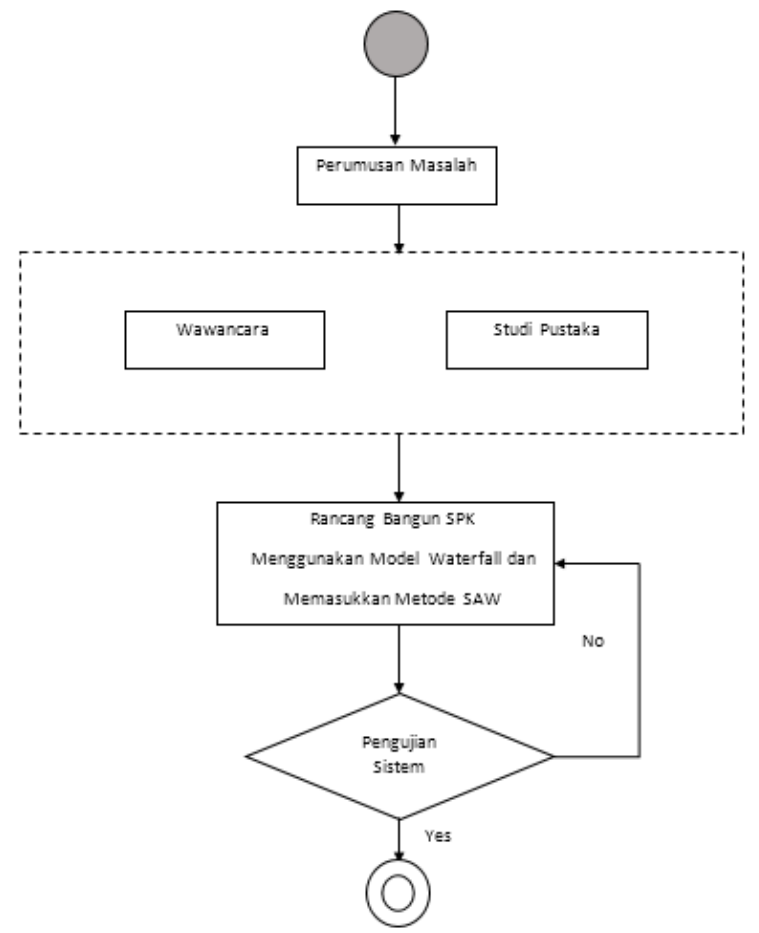

Gambar 2 Kerangka Berpikir

\section{B. Metode Pengumpulan Data}

Metoda pengumpulan data yang dilakukan dalam penelitian ini adalah:

\section{Wawancara}

Pada tahap ini penulis melakukan pengumpulan data dengan cara melakukan wawancara secara langsung dengan Ahli Gizi mengenai menu-menu apa saja yang baik dan sehat bagi penderita hipertensi disertai dengan persentase penilaian kandungan gizi dalam makanan yang boleh dikonsumsi oleh penderita hipertensi. Data yang didapat dari wawancara dapat dikategorikan sebagai sumber primer karena didapatkan langsung dari sumber pertama. Hasil Wawancara tentang persentase dari kriteria dapat dilihat pada gambar 3

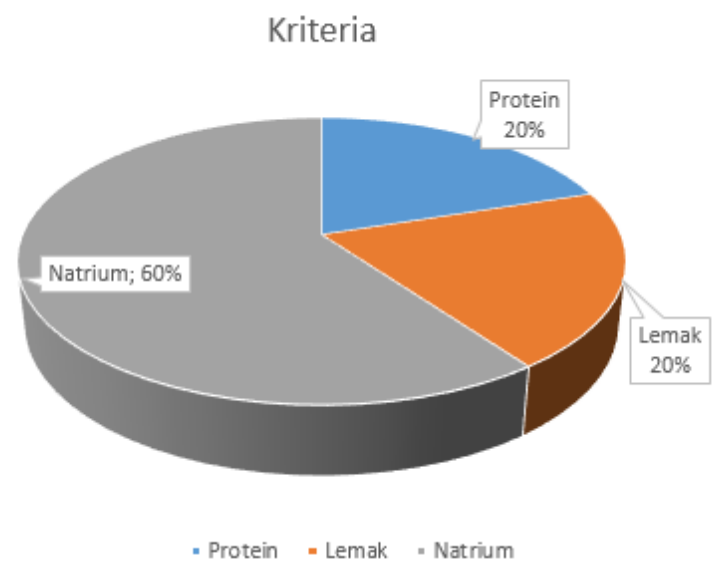

Gambar 3 Persentase Kriteria
Pada gambar 3 menjelaskan bahwa persentase kriteria adalah protein memiliki nilai $20 \%$, lemak memiliki nilai $20 \%$, dan natrium memiliki nilai $60 \%$. Dari ketiga kriteria yang ada terdapat dua kriteria yang mempengaruhi peningkatan tekanan darah yaitu lemak dan natrium dan satu kriteria yang menurunkan tekanan darah yaitu protein.

\section{Analisis Kebutuhan}

Perancangan dan pembuatan Sistem pendukung keputusan pemilihan menu bagi penderita hipertensi ini memerlukan data agar bisa menghasilkan sistem yang baik. Data-data tersebut diperoleh dengan cara melakukan wawancara dengan ahli gizi atau orang-orang yang berhubungan dengan gizi serta mencari referensi dari buku-buku atau artikel-artikel yang berhubungan dengan menu diet hipertensi, sehingga data yang diperoleh dapat dimasukkan ke dalam database. Pada tahap ini peneliti melakukan perencanaan dalam pembuatan aplikasi.

\section{Spesifikasi Pengguna}

Untuk tahap ini spesifikasi pengguna merupakan penjelas an tanggung jawab aktor yang memakai aplikasi ini. Spesifikasi pengguna dapat dilihat pada tabel 1.

\section{TABEL 1 SPESIFIKASI PENGGUNA}

\begin{tabular}{|l|l|l|}
\hline Pengguna & Peran & Tanggung Jawab \\
\hline Penderita & User & Aktor yang \\
Hipertensi & & menggunakan sistem \\
& & pendukung keputusan \\
& & pemilihan menu bagi \\
& & penderita hipertensi \\
& & melakukan proses \\
& & mengelola data \\
& & makanan dan kriteria \\
& & dan matriks serta \\
& & hasil perankingan \\
& & \\
\hline
\end{tabular}

\section{Spesifikasi Aplikasi}

Pada tahap spesifikasi aplikasi ini yaitu menjelaskan fungsifungsi dari setiap fitur yang dibuat dari aplikasi yang akan dibuat. Spesifikasi aplikasi sistem pendukung keputusan pemilihan menu bagi penderita hipertensi dapat dilihat pada tabel 2.

TABEL 2 SPESIFIKASI APLIKASI

\begin{tabular}{|l|l|}
\hline Fitur & Fungsi \\
\hline Tambah data makanan & $\begin{array}{l}\text { Menambah data makanan dari } \\
\text { aplikasi ke dalam database }\end{array}$ \\
\hline Edit data makanan & $\begin{array}{l}\text { Mengelolah dan } \\
\text { memperbarui data makanan }\end{array}$ \\
\hline Hapus data makanan & $\begin{array}{l}\text { Menghapus data makanan } \\
\text { dalam database }\end{array}$ \\
\hline Edit data kriteria & $\begin{array}{l}\text { Mengelolah dan } \\
\text { memperbarui data makanan }\end{array}$ \\
\hline
\end{tabular}


E-journal Teknik Informatika, Volume 8, No 1 (2016), ISSN : 2301-8364

\section{Desain Modeling}

Pada tahap ini, semua hasil analis a kebutuhan pengguna dan kebutuhan sistem aplikasi sistem pendukung keputusan pemilihan menu bagi penderita hipertensi dalam bentuk rancangan basis data, rancangan antarmuka dan uml.

\section{Rancangan Basis Data}

Database dari aplikasi ini sendiri dirancang menggunakan MySQL. Penekanan dari data yang disimpan secara temporary merupakan data yang diperoleh dari kriteria dan alternatif serta perhitungan-perhitungan pada matriks pembobotan, dan perankingan. Tabel-tabelyang ada didalamrancangan database beserta nama-nama atribut yang ada dalam masing-masing tabel dan tipe datnya

TABEL 3 T ABEL KRITERIA

\begin{tabular}{|l|l|l|l|}
\hline No & Field & Type & \multirow{2}{*}{} \\
\hline 1 & Id_kriteria & Int $(10)$ & Primary key \\
\hline 2 & Nama_kriteria & Varchar(255) & \\
\hline 3 & Bobot_kriteria & Double(8,2) & \\
\hline 3 & Created_at & Timestamp & \\
\hline 4 & Update_at & Timestamp & \\
\hline
\end{tabular}

TABEL 4 T ABEL MAKANAN

\begin{tabular}{|l|l|l|l|}
\hline No & Field & Type & \multirow{2}{*}{} \\
\hline 1 & Id_makanan & $\operatorname{Int}(10)$ & Primary key \\
\hline 2 & Nama_makanan & Varchar(255) & \\
\hline 5 & Created_at & Timestamp & \\
\hline 6 & Update_at & Timestamp & \\
\hline
\end{tabular}

TABEL 5 T ABEL MATRIKS

\begin{tabular}{|l|l|l|l|}
\hline No & Field & Type & \multirow{2}{*}{} \\
\hline 1 & Id_matrik & $\operatorname{Int}(10)$ & Primary key \\
\hline 2 & Id_makanan & $\operatorname{Int}(10)$ & \\
\hline 3 & Kriteria1 & $\operatorname{Varchar}(255)$ & \\
\hline 4 & Kriteria2 & Varchar(255) & \\
\hline 5 & Kriteria3 & Varchar(255) & \\
\hline 6 & Created_at & Timestamp & \\
\hline 7 & Update_at & Timestamp & \\
\hline
\end{tabular}

TABEL 6 TABEL BOBOT KRITERIA

\begin{tabular}{|l|l|l|l|}
\hline No & Field & Type & \\
\hline 1 & Id & $\operatorname{Int}(10)$ & Primary key \\
\hline 2 & Id_makanan & $\operatorname{Int}(10)$ & \\
\hline 2 & Rank & Double $(8,2)$ & \\
\hline 3 & Created_at & Timestamp & \\
\hline 4 & Update_at & Timestamp & \\
\hline
\end{tabular}

Hubungan atau relasi antara tabel makanan, tabel kriteria, dan tabel matriks dan tabel evaluasi merupakan relasi antar tabel one to many. One to many merupakan "Setiap baris data dari tabel pertama dapat dihubungkan ke satu baris atau lebih data pada tabel ke dua". Relasi antar tabel terjadi antara tabel makanan dan tabel matriks serta tabel evaluasi. Sedangkan untuk tabel kriteria berdiri sendiri karena karena prosesnya sudah berjalan di dalam php. Relasi antar tabel dapat dilihat pada gambar 4.

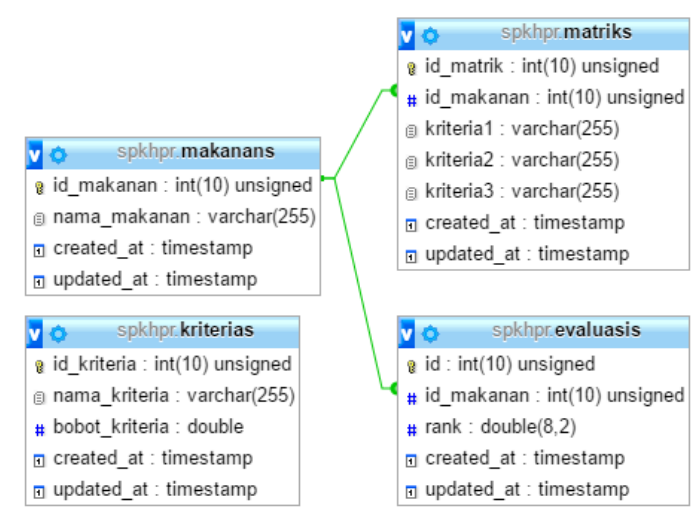

Gambar 4 Relasi Antar Tabel

Rancangan Antar Muka

\begin{tabular}{|c|c|}
\hline Header & Menu \\
Beranda Kriteria Makanan Matrik Hasil Akhir \\
\hline Page \\
Gambaran Umum \\
Sistem pendukung Keputusan \\
Simple Additive Weighting \\
Footer \\
\hline
\end{tabular}

Gambar 5 Storyboard halaman awal aplikasi

Sebuah proses perancangan membutuhkan pengetahuan mengenai berbagai teknik atau model perancangan yang dapat digunakan. Rancangan antarmuka dibuat menarik, interaktif, mudah dipelajari, mudah digunakan dan mudah dipahami. Rancangan interface atau antarmuka yang dibuat untuk membuat aplikasi sistem pendukung keputusan pemilihan menu bagi penderita hipertensi

\section{Use Case Diagram}

Use case diagram dalam sistem pendukung keputusan pengguna yang di gambarkan dengan aktor hanya berjumlah satu pengguna. Pengguna dapat mengatur data kriteria namun hanya dapat mengubah data, jika ada kesalahan dalam penulisan kata atau mengubah bobot kriteria. Pengguna dapat mengatur data makanan dengan menginput/menambahkan data makanan, mengedit data makanan dan menghapus data makanan. Pada bagian kriteria. Pengguna dapat melihat pembobotan alternatif terhadap kriteria, sehingga akan menghasilkan nilai normalisasi. Pengguna dapat melihat nilai pada makanan yang akan dilakukan proses perhitungan 
menggunakan metode saw, dan akan menghasilkan ranking makanan

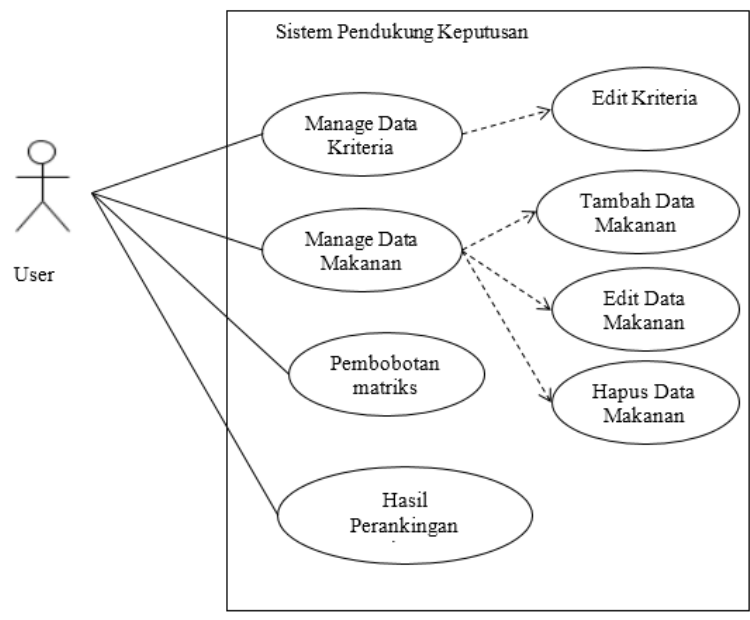

Gambar 6 Use Case Diagram

\section{Activity Diagram Kriteria}

Activity diagram ini dipergunakan user yang hanya dapat mengubah data kriteria, activity diagram kriteria dapat dilihat pada gambar 7 .

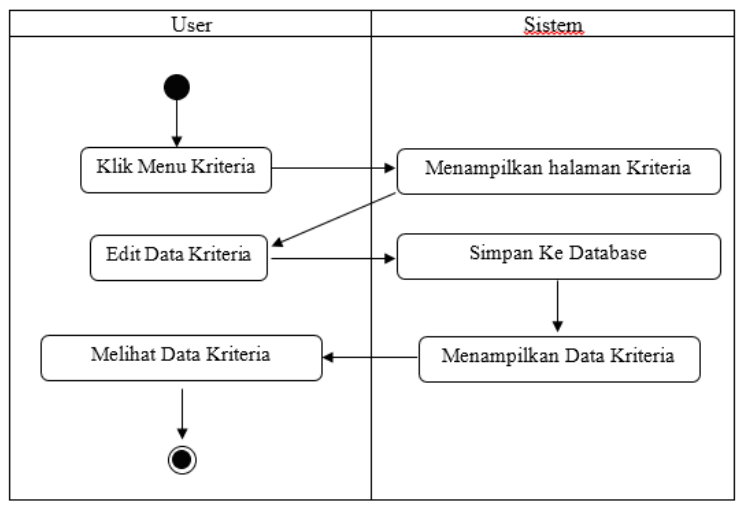

Gambar 7 Activity Diagram Kriteria

\section{Activity Diagram Makanan}

Activity diagram ini dipergunakan user untuk menambah data makanan. Berikut gambar activity diagram, dapat dilihat pada gambar 8 .

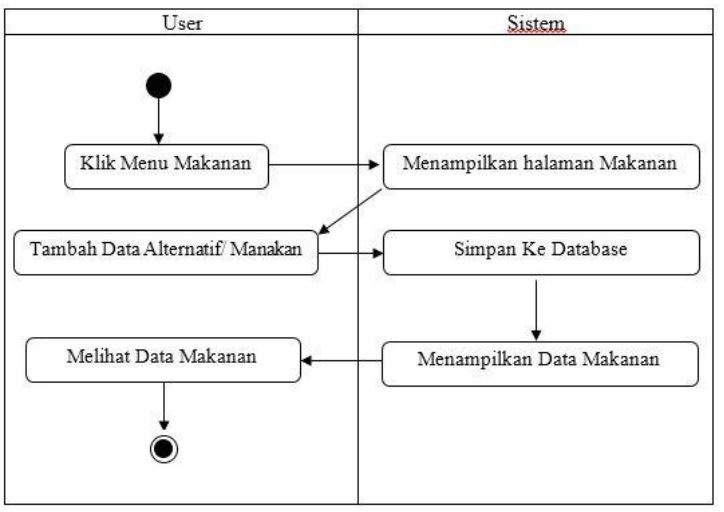

Gambar 8 Activity Diagram Tambah Data Makanan
IV. Hasil dan Pembahasan

\section{Pembahasan Aplikasi Sistem Pendukung Keputusan}

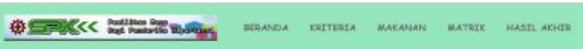

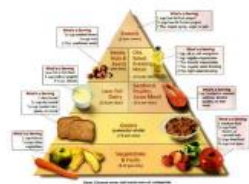

Selamat Datang

Pengunjung!!!

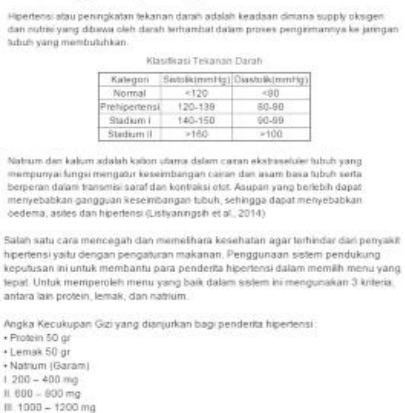

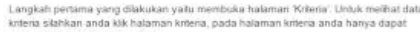

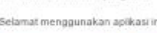

* Tenteng $\mid$ a Hubung

Gambar 9 Halaman Beranda

Halaman beranda merupakan tampilan utama sistem pendukung keputusan yang terdiri dari lima menu, yaitu beranda, kriteria, makanan, matriks dan hasil akhir, pada halaman ini hanya berisikan informasi penjelasan tentang sistem pendukung keputusan metode SAW, dapat dilihat pada gambar 9 .

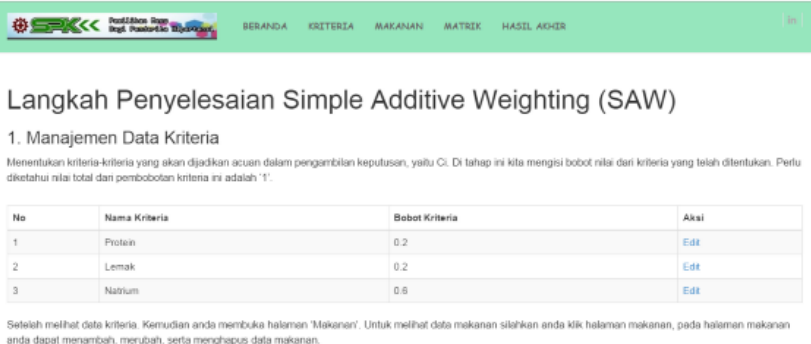

Gambar 10 Halaman Kriteria

Halaman kriteria untuk melihat data kriteria yang sudah di masukkan ke dalam sistem, pengguna dapat mengedit data kriteria, pada halaman ini tidak ada fitur penambahan kriteria, karena pada proses perhitungan nanti akan menggunakan matriks perbandingan antara kriteria dengan alternatif, jadi pada halaman ini hanya menampilkan 3 kriteria, dapat dilihat pada gambar 10 .

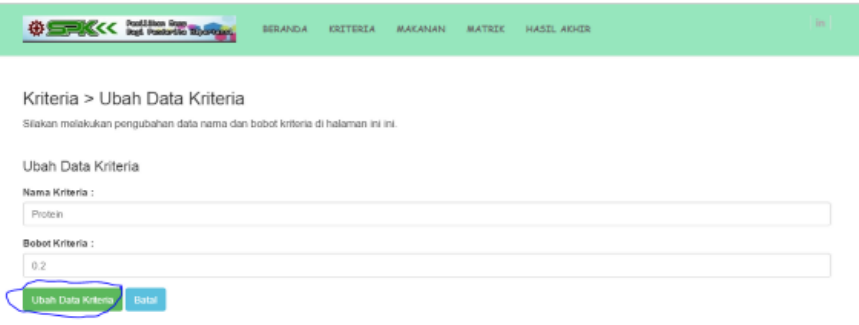

Gambar 11 Halaman Edit Kriteria 
E-journal Teknik Informatika, Volume 8, No 1 (2016), ISSN : 2301-8364

Halaman edit kriteria untuk mengubah data kriteria yang ada dengan mengisi nama kriteria dan bobot kriteria yang akan dirubah kemudian klik Ubah Data Kriteria jika sudah merubah data yang ada, dapat dilihat pada gambar 11 .

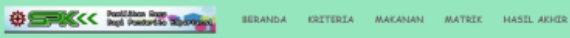

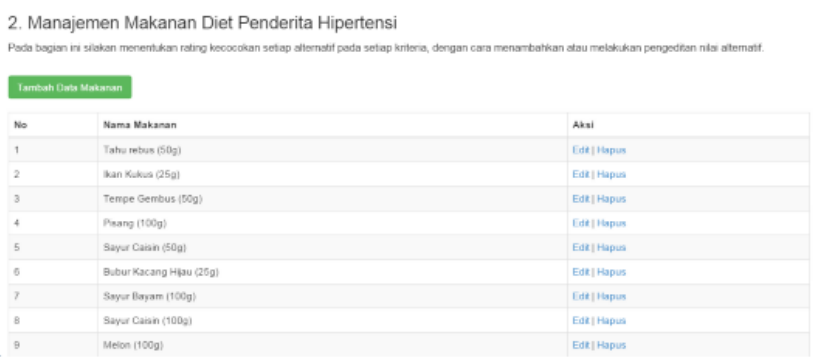

Gambar 12 Halaman Makanan

Halaman makanan berfungsi untuk melihat data makanan yang sudah dimasukkan ke database, pada halaman ini pengguna bebas menambahkan data makanan, mengedit makanan yang sebelumnya sudah di tambahkan dan juga menghapus data, dapat dilihat pada gambar 12

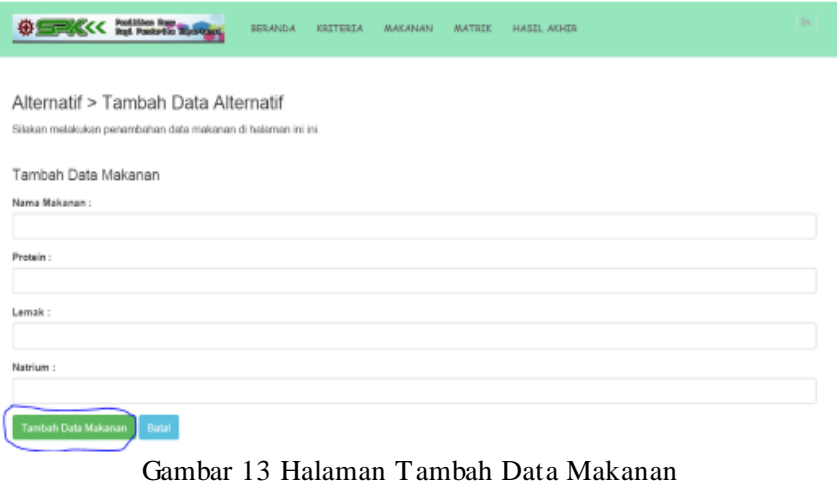

Halaman tambah makanan untuk menambahkan data makanan baru dengan mengisi form nama makanan dan nilainilai kriteria yang ada. Jika sudah diisi data makanan silahkan klik Tambah Data Makanan maka data akan ditambahkan ke dalam database dapat dilihat pada gambar 13.

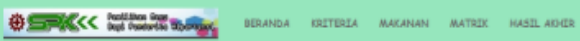

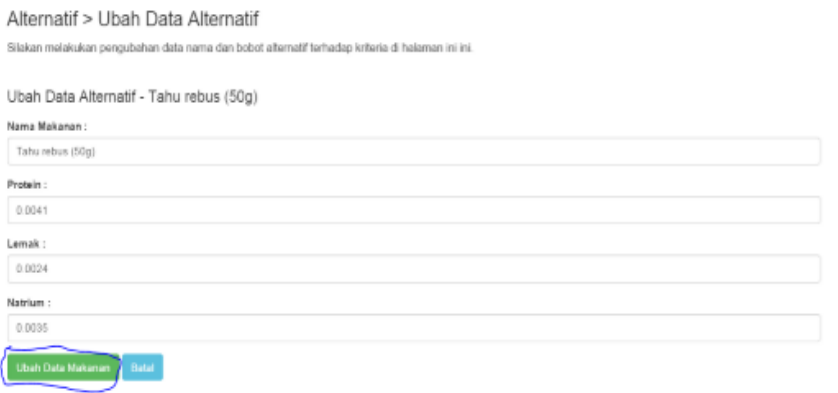

Gambar 14 Halaman Edit Data Makanan
Halaman edit untuk mengubah data makanan jika ada data yang salah atau kurang lengkap dengan mengisi form nama makanan dan nilai-nilai kriteria yang ada kemudian klik Ubah Data Makanan jika sudah merubah data yang ada, dapat dilihat pada gambar 14.

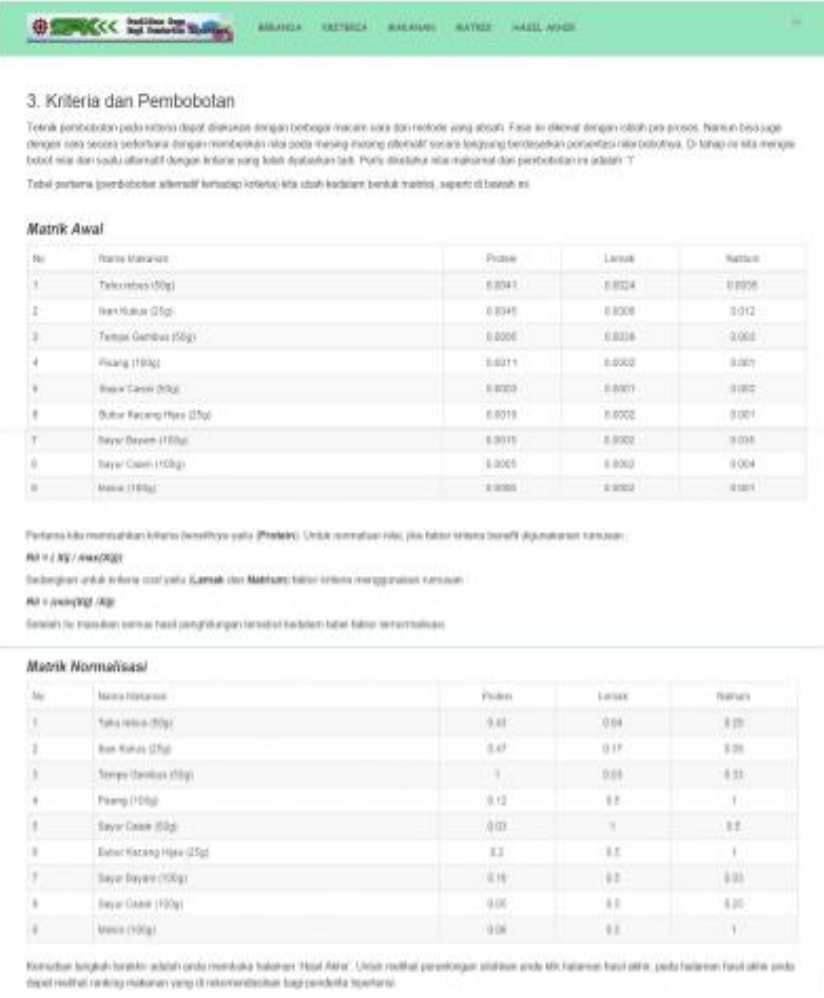

Gambar 15 Halaman Matriks

Halaman matriks berfungsi untuk melakukan perbandingan antara kriteria dengan berdasarkan nilai yang di masukkan di database, setelah itu akan di lanjutkan dengan proses perhitungan saw untuk menampilkan hasil normalisasi, dapat dilihat pada gambar 15 .

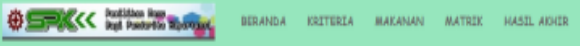

\section{Hasil Akhir}

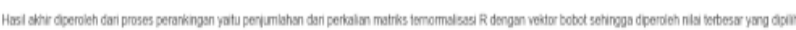

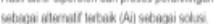

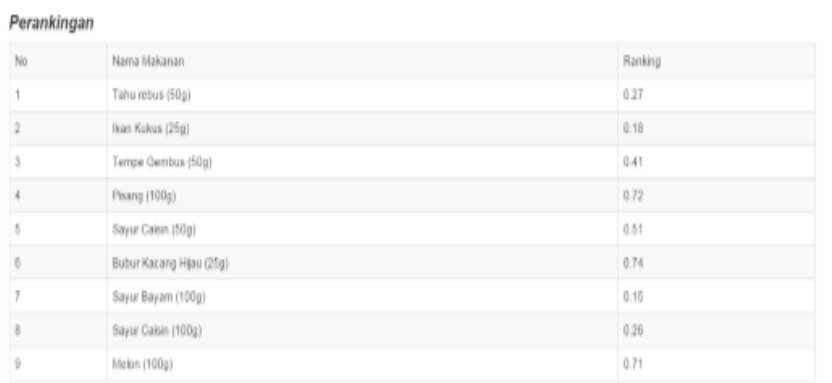

Gambar 16 Halaman Hasil Akhir 
Setelah sudah mendapat tabel matriks normalisasi, klik menu hasil ranking untuk melihat ranking makanan, dapat dilihat pada gambar 16.

\section{PENUTUP}

\section{A. Kesimpulan}

Kesimpulan yang di dapat pada penelitian ini adalah sebagai berikut :

- Sistem Pendukung Keputusan Pemilihan Menu Bagi Penderita Hipertensi dengan menggunakan metode SAW berhasil dibangun.

- $\quad$ Sistem Pendukung Keputusan Pemilihan Menu Bagi Penderita Hipertensi dengan menggunakan metode SAW membantu bagi penderita hipertensi dalam menentukan menu makanan yang baik dengan memberikan rekomendasi makanan yang baik bagi penderita berupa ranking makanan berdasarkan bobot yang diperoleh.

\section{B. Saran}

Sistem pendukung keputusan pemilihan menu bagi penderita hipertensi yang telah di buat masih perlu dikembangkan agar kinerja sistem menjadi lebih baik. Saran untuk pengembangan penelitian lebih lanjut terhadap penelitian ini adalah:

- Apabila kedepan ada yang mengembangkan aplikasi ini karena keterbatasan usia dan kriteria agar menjadi lebih baik

- Penulis berharap dari aplikasi ini bisa mengembangkan dengan lebih banyak fitur-fitur yang bagus dan menarik

\section{DAFTAR PUSTAKA}

[1] Amelia Yusnita dan Rosiana Handini. 2012. Sistem Pendukung Keputusan Menentukkan Lokasi Umah Makan Yang Strategis Menggunakan Metode Naive Bayes. Seminar Nasional Teknologi Informasi \& Komunikasi Terapan 2012 (Semantik 2012) ISBN 979 26 - 0255 - 0. Semarang, 23 Juni 2012

[2] Arianto et al.. Aplikasi Pelayanan Dan Keluhan Gangguan Telepon Pelanggan Di Pt Telekomunikasi Indonesia Tbk Kancatel Subang.

[Online] Tersedia

https://www.academia.edu/3798415/Jurnal_telkom

Tanggal Akses 25 Maret 2016

[3] Arista Novian. 2013. Kepatuhan Diit Pasien Hipertensi. Jurnal Kesehatan Masyarakat. KEMAS 9 (1) (2013) $100-105$

[4] Asep Kamaludin. 2012. Sistem Pendukung Keputusan Dalam Pemilihan Alternatif Alat Kontrasepsi Menggunakan Simple Additive Weighting.
[5] Astri Herdiyanti dan Utami Dewi Widianti. 2013. Pembangunan SistemPendukung Keputusan Rekrutmen Pegawai Baru Di PT. ABC. Jurnal Ilmiah Komputer dan Informatika (KOMPUTA) 49 Vol. 2, No. 2, Oktober 2013, ISSN : 2089-9033

[6] Listiyaningsih et al. 2014. Asupan Sumber Natrium, Rasio Kalium Natrium, Aktivitas Fisik, Dan Tekanan Darah Pasien Hipertensi. Yogyakarta

[7] Lukman et al. 2014. Rancang Bangun Sistem Informasi Penggajian Pegawai Dan Remunerasi Jasa Medis Pada Rumah Sakit Bedah Surabaya. Surabaya. JSIKA Vol 3, No 1 (2014)/ ISSN 2338-137X.

[8] Murdani. 2013. Sistem Pendukung Keputusan Pemilihan Pekerjaan Bagi Alumni Teknik Informatika Dengan Metode Simple Additive Weighting (SAW). Pelita Informatika Budi Darma, Volume : IV, Nomor: 2, Agustus 2013, ISSN : 2301-9425

[9] Utami Dewi Widianti. 2012. Pembangunan Sistem Informasi Aset Di Pt.Industri Telekomunikasi Indonesia (Persero) Berbasis Web. Jurnal Ilmiah Komputer dan Informatika (KOMPUTA) Volume. I Nomor. 2, Bulan Oktober 2012 - ISSN :2089-9033. Bandung

[10] Wiwekananda.. Perancangan Dan Implementasi Sistem Interaktif Jurnal Pada Sistem Akuntansi (Aiso) Pt. Dimata Sora Jayate
[Online]
Tersedia

http://ojs.unud.ac.id/index.php/JLK/article/download/2

622/1842 Tanggal Akses 23 Maret 2016

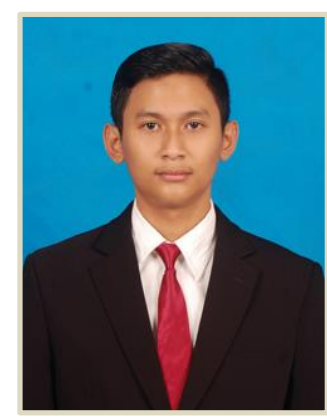

Sekilas dari penulis dengan nama lengkap Harris Adhi Oktaviantho Suparno, lahir pada tanggal 13 Oktober 1993 di kota Manado, Provinsi Sulawesi Utara, Anak Pertama dari Dua Bersaudara. Dengan Pendidikan Sekolah Dasar Katolik Sta Theresia Malalayang. Kemudian melanjutkan ke Sekolah Menengah Pertama Katolik Sta Theresia Malalayang. Kemudian melanjutkan ke Sekolah Menengah Atas Negeri 9 Binsus Manado. Setelah lulus tahun 2011 melanjutkan ke Perguruan Tinggi di Universitas Sam Ratulangi Manado dengan mengambil Jurusan Teknik Informatika. Pada tahun 2015 bulan Januari penulis membuat Skripsi demi memenuhi syarat Sarjana (S1) dengan penelitian berjudul Sistem Pendukung Keputusan Pemilihan Menu Bagi Penderita Hipertensi yang dibimbing oleh dua dosen pembimbing yaitu Oktavian A. Lantang, ST., MTI. dan Arie Lumenta, ST., MT sehingga pada tanggal 29 Juni 2016 penulis resmi lulus di Teknik Informatika Universitas Sam Ratulangi Manado dan menyandang gelar Sarjana Komputer. 